INTERNATIONAL JOURNAL OF RESEARCHES IN BIOSCIENCES, AGRICULTURE AND TECHNOLOGY (C) VISHWASHANTI MULTIPURPOSE SOCIETY (Global Peace Multipurpose Society) R. No. MH-659/13(N) www.vmsindia.org

\title{
HISTOPATHOLOGY OF HENNEGUYA NOTOPTERIDAE QADRI, 1965 INFECTION IN FRESHWATER FISHES
}

Dabhade D.S. and J. R. Somatkar

P.G. and Research Department of Zoology,

R. A. Arts, Shri M. K. Commerce and Shri S.R. Rathi Science College,

Washim. 444505, dsdabhade12345@gmail.com

\begin{abstract}
:
Examination of freshwater fishes from Ekburgi reservoir in Washim region of Maharashtra revealed the presence of Myxosporean species of the genus Henneguya Thelohan, 1892, on gill surface of cultured freshwater fishes. The Henneguya species reported during the present research is Henneguya notopteridae Quadri,1965 with heavy infection on gill surface and kidney of freshwater fishes Catlacatla, Labeo rohita and Notopterus notopterus. The present research emphasizes the morphometrix of Henneguya notopteridae parasite together with histopathological impact on fish. Henneguya notopteridae infected fish exhibits haemorrhagic condition with necrotic changes in the epithelia and connective tissue of gills. Pronounced inflammation has been observed leading to structural disorganization of secondary lamellae. Nearly complete loss of respiratory function, accompanies infection.
\end{abstract}

Keywords: Henneguya, Histopathology, Freshwater fish, Infection

\section{Introduction:}

Myxosporidia are almost exclusively fish parasites. Some species are very harmful and can weaken or kill their hosts, leading to important economic losses (Okaeme et al. 1988). These parasites affecting a wide range of tissues. They are extremely abundant and diverse group of organism dispersed in native and pond reared fish population. Among the myxosporeans, the genus Henneguya Thelohan, 1892 which includes at least 126 species (Lom \& Dykova, 1992), is one of the largestnine genera in the family Myxobolidae infecting fresh water and marine fishes. Infection of Henneguya species is reported worldwide by various workers from freshwater fishes includes Mc Craren et al. (1975), Dykova and Lom (1978), Kalavati and Narasimhamuri (1985), Molnar (1988), Ali (1999), Martins et al. (1999), Eiras et al. (2002, 2005), Kalavati and Nandi (2007) that results in serious losses. Therefore the present study was carried out to study the effect of Henneguya notopteridae Qadri, 1965 species with the help of histopathological analysis.

\section{Material and Methods:}

The host fishes for the present study were collected from various dams and local fish market from 2010 to 2014 . The collected fishes were brought to laboratory for necropsy procedure for examination of Myxozoan parasites. As such when cysts or abnormalities in the organs were noticed, myxozoans were suspected. For temporary mounting of parasites, fresh saline wet mounts were prepared. Fresh spores were mounted in Lugol's solution for presence of iodinophilous vacuoles in sporoplasm and Indian ink for presence of mucous coat around the spore. Extrusion of polar filament was achieved by treatment of fresh spores with $10 \% \mathrm{KOH}$. For permanent preparation, a smear using fresh spores was prepared and allowed to air dry. Then these spores were fixed in $10 \%$ buffered formalin and stained in Giemsa's stain (Cone and Anderson, 1977) and mounted in DPX. Examinations of preparations were made under Olympus phasecontrast microscope at $100 \mathrm{x}$ magnification and The photographs of the slide were taken with the digital camera and drawing were made with Camera Lucida to illustrate the structure of spore. Measurements of spores were taken in micrometer with the aid of calibrated ocular micrometer. For histopathological analysis, the cysts were fixed in $10 \%$ buffered formalin for $24 \mathrm{~h}$, embedded in paraffin, cut into $4 \mu \mathrm{m}$ thick sections and stained with hematoxylin and eosin. The photographs of the histopathology slides were taken with the digital camera of microscope. Identification of Henneguya species was done using standard literature of Kudo (1966), Eiras et al., (2002), Kalavati and Nandi (2007).

\section{Result and Discussion:}

The present study clearly demonstrate the presence of Henneguya notopteridae Qadri, 1965 species from gill surface and from kidney of some freshwater fishes collected from Ekburgii dam.

\section{Henneguya notopteridae (Qadri, 1965)} Taxonomic Summary-

Type host: Notopterus notopterus, Labeorohita, Catla catla

Parasite: Henneguya notopteridae Qadri, 1965.

Type locality: Ekburgi dam, Washim, Maharashtra

Site of infection: Gills, Kidney 
Holotype: In slide no. H18/2/2013, deposited in P.G. and Research department of Zoology, R.A. College, Washim Dist. Washim Maharashtra.

\section{Morphometrix-}

Length of Body spore: $\quad 9.6 \mu \mathrm{m}$

Width of spore: $\quad 2.4 \mu \mathrm{m}$

Length of Polar capsule: Large: $4.8 \mu \mathrm{m}$

$$
\text { Small: } 3.6 \mu \mathrm{m}
$$

Width of Polar capsule: Large: $1.4 \mu \mathrm{m}$;

Small: $1.2 \mu \mathrm{m}$

Total length with caudal appendage: $33.6 \mu \mathrm{m}$

\section{Plasmodia.}

Small, white and round. Each plasmodium with 14-15 spores.

\section{Spore}

Spore elongated, ellipsoidal with long divided caudal processes; anterior end fusiform, pointed, posterior end flattened; sutural ridge fine; polar capsules elongated, unequal, one pyriform and the other with longduct; sporoplasm homogenous, iodinophilous vacuole round, located in the posterior half of the spore.

\section{Description:}

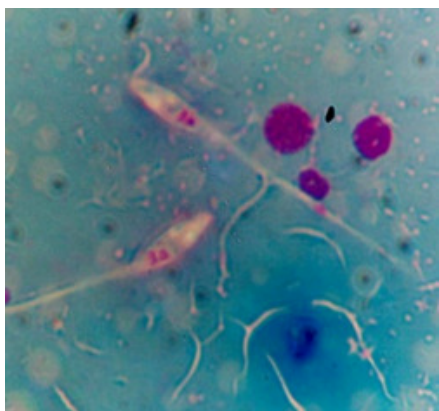

Microphotograph of the spore of Henneguy a notopteridae (1000X)

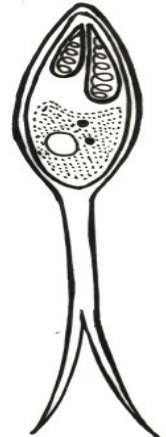

Spores of Henneguya notopteridae (Diagramatic)
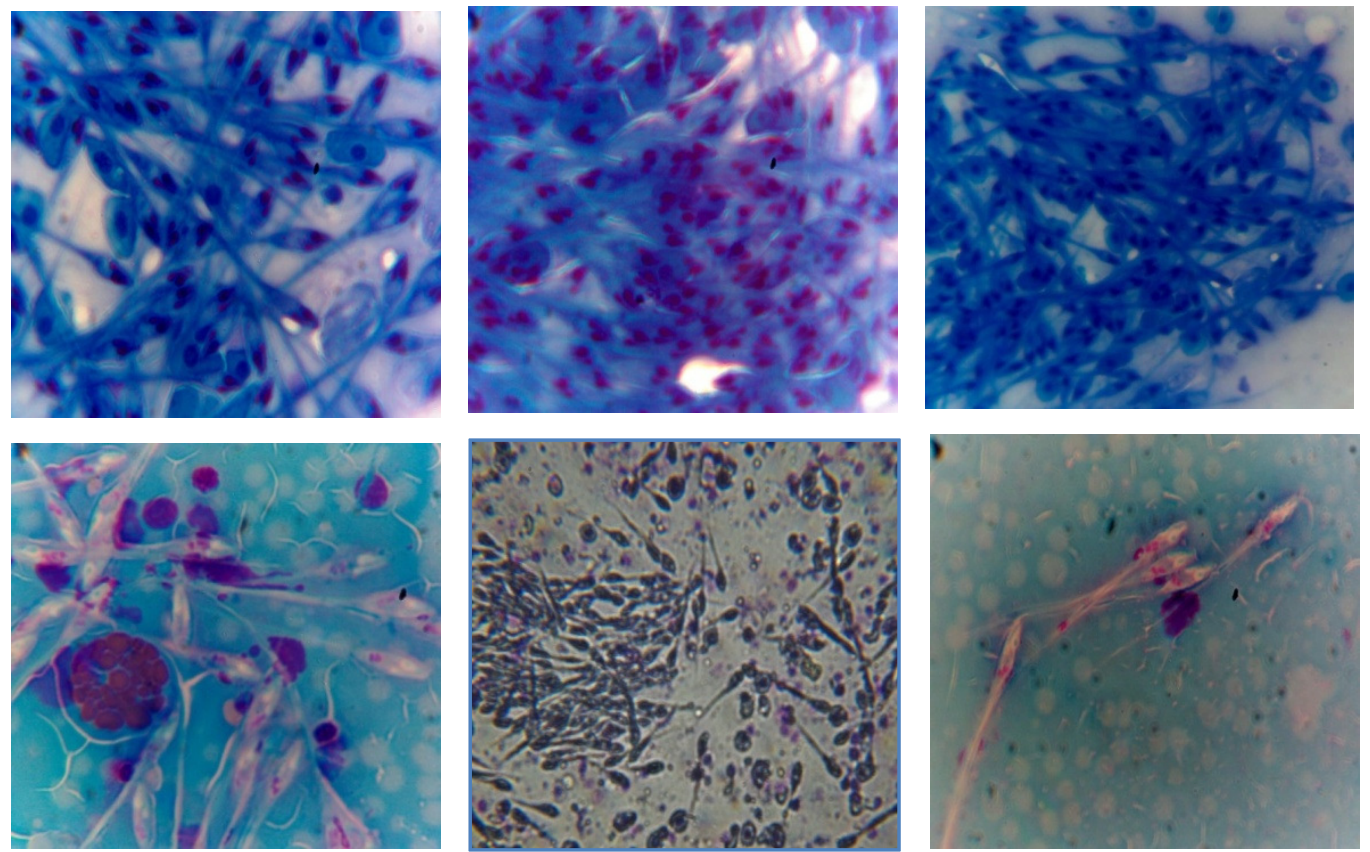

Photoplate I: Examples of appearance of stained Myxosporeans spores of Henneguya notopteridae (Qadri, 1965) with high population (Giemsa staining with magnification of 400X and 1000X) 


\section{Histopathology of fishes infected with Henneguya notopteridae (Qadri, 1965) :}

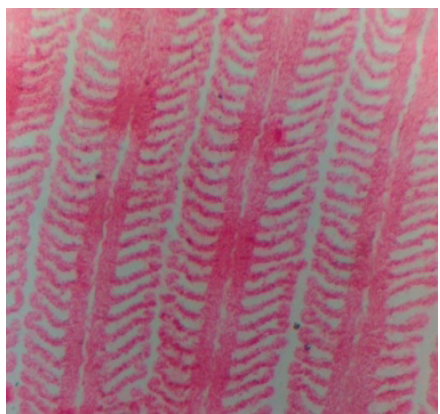

1. Gills of healthy Freshwater fish (200x)

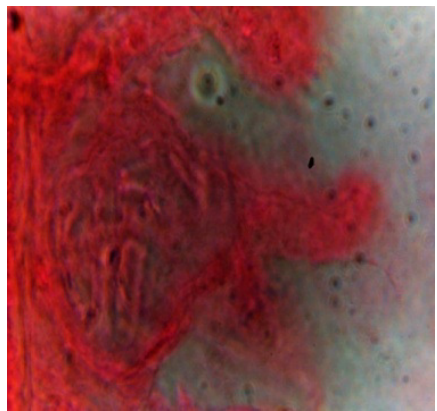

3. Gills of Infected Notopterus fish (400X)

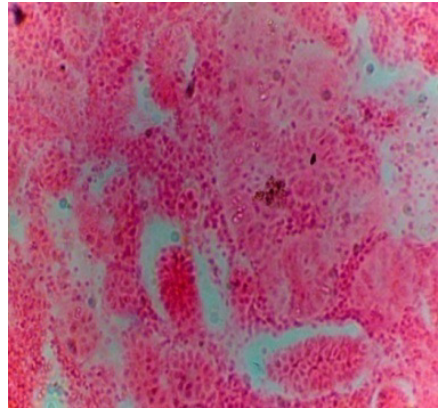

5. Kidney of Healthy Freshwater fish (200X)

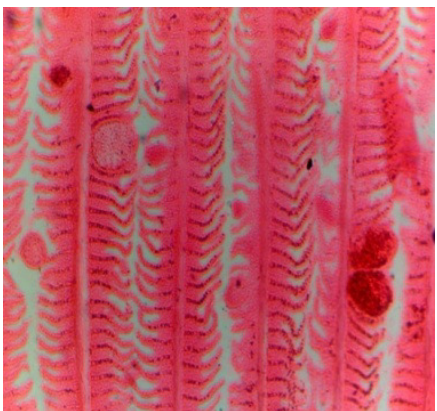

2. Gills of Infected Labeo rohita fish (200x)

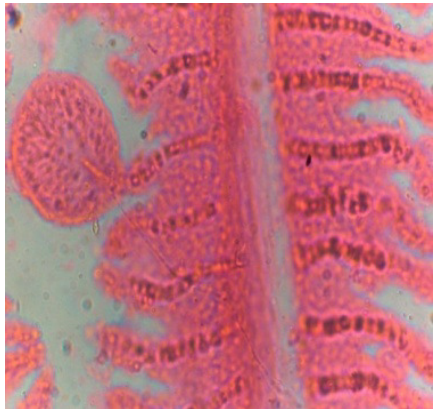

4. Gills of infected Catla catla fish (400X)

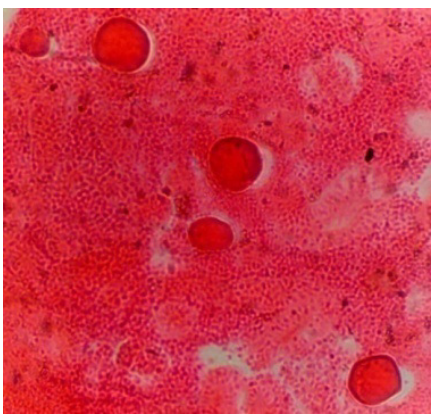

6. Kidney of Infected Notopterus fish (200X)

Photoplate 2: Showing histology of normal gills and histopathology of infected fishes (Eosin and haematoxylin staining)

In the present study, the histopathological analysis of gills infected with Henneguya ;indicates presence of myxosporean cysts of Henneguya at several developmental stages over the entire lamellae. The given study reports two types of branchial infections known as interlamellar form that develop cyst between the lamellae and intralamellar form that develop cyst within the lamellae. In intra lamellar type of plasmodia spore development occurs within the capillaries or blood vessels of gill lamellae that result in opaque, spore filled cysts found in large numbers. Intralamellar vascular type of plasmodia which is the common type with plasmodia formed in the vascular network of the gill lamellae. These plasmodia may be large or small in size occupying single lamella causing dilation of lamellae and deformation in adjacent gill lamellae. Each plasmodium was bounded by a thin membrane and its lumen was filled with large number of spores, infiltrated epithelial cells and macrophages. The smaller cyst may be seen at the base; centre and tip of the gill lamellae and larger cyst occupy the whole length of gill lamellae causing hyperplasia of the gill epithelium and atrophy of gill lamellae at the cyst site. Hyperplasia is a common and unspecified response to parasitic infection 
causing fusion of secondary lamellae resulting in reduction of respiratory surface and in interlamellar type of plasmodia spore development occurs among basal cells between gill lamellae. As spore formation progresses, lamellae tissue become greatly hypertrophied and loose all its normal structure. Infected fish exhibits haemorrhagic condition with necrotic changes in the epithelia and connective tissue of gills. Pronounced inflammation has been observed leading to structural disorganization of secondary lamellae. Nearly complete loss of respiratory function accompanies infection. Fish exhibits signs of anoxia and swims at surface of pond with flared gill operculae. Similar fish response was reported by McCrarenet al. (1975) reporting both types of plasmodia on gills of Channel catfish with most outstanding interlamellar branchial form responsible for significant losses among immature catfish and unique papillomotous form. According to Dykova and Lom (1978), the response of soft tissues of fish to myxosporidian infections involved displacement, atrophy or hyperplasia of the tissue surrounding the plasmodium during its growth and maturation. In more advanced stages, when the cysts are full of mature spores, an inflammatory reaction occurs, resulting in the rapid replacement of cyst by granulomatous tissues. Similar observations have also been made by Kalavati and Narasimhamuri (1985) in Chhana punctata with $H$. waltairensis. Molnar (1988) also reported hyperplasia and the formation of a thick layer of granular tissue. ElMatbouliet al. (1992) confirmed these results with H. psorospermica. Martins and Souza(1997)studied the gills of Piaractus parasitized by Henneguya sp.Ali (1999) reported that the intralamellar form of Henneguya that develops outside the blood capillaries of the gill filament in Nile perch, Lates niloticus. In a similar histopathological study of the gills of $S$. lucioperca parasitized by $H$. creplini, which produce same kind of cysts, as described in the present study.Martins et al. (1999) described epithelial, haemorrhage and an intense inflammatory mononuclear infiltrate in the secondary lamellae of Leporinus macrocephalus infected with $H$. leporinicola.

Barassa et al., (2003) reported that $H$. chydadea causes histopathological alterations included compression of capillaries and retraction of the neighbouring lamellae that results in structural deformation of gills. Barrasa et al. (2003a) also reported $H$. curvata causing deformation of lamellar structure which led to slight oedema which further results in fusion of secondary lamellae and epithelial cells proliferate around plasmodia and results in thickening of epithelial surface. Adriano et al. (2009) made similar observations that presence of plasmodia affect the gill functions and drastically reduces the respiratory surface.

The result of the present study indicates that these parasites are potentially pathogenic, and that a high parasite load could compromise normal functioning of fish.

\section{References:}

Adriano E.A., Arana S, Alves A.L., Silva M.R., Ceccarelli PS, Henrique-Silva F, Maia AA (2009). Myxobolus cordeiro in. sp., a parasite of Zungaro jahu (Siluriformes: Pimelodiade) from Brazilian Pantanal: morphology, phylogeny and histopathology. Vet. Parasitol. vol.162: 221-229.

Ali M.A. (1999): Henneguya ghaffarispna (Myxozoa :Myxosporea), infecting the Nile perch Lates niloticus (Teleostei: Centropomidae). Diseases of aquatic organisms. Vol.38: 225-230

Barassa B., Adriano E.A., Arana and N.S. Cordeiro (2003): Henneguya curvata sp. Myxosporea: Myxobolidae) parasitizing the gills of serrasalmus spilopleura (Characidae: Serrasalminae), a south American freshwater. Fish. Folia Parasitologica 50:151-153

Cone D.K. and R.C. Anderson (1977): Myxosporidian parasites of Pumpkinseed (Lepomisgibbosus L.) from Ontario. J. Parasit vol.63: 657-666.

Dykova I and Lom $\mathbf{J}$ (1978). Histopathological changes in fish gills infected with myxosporidian parasites of genus Henneguya. J. Fish Biol.vol.12: 197-202.

Eiras J.C,, Takemoto R.M and Pavanelli G.C. (2009). Henneguya corruscansn. sp. (Myxozoa, Myxobolidae) a parasite of Pseudoplatys tomacor ruscans (Osteichthyes, Anostomidae) from Parana river, Brazil, a morphological and morphometric study. Vet. Parasitol.vol.159:154-158.

Eiras J.C. (2002): Synopsis of the species of the genus Henneguya Thelohan, 1892 (Myxozoa: Myxosporea: Myxobolidae). Syst. Parasitol. 52:43-54.

Eiras J.C., Pavanelli G.C. and R.M. Takemoto (2004): Henneguya paranaensis sp. n. (Myxozoa, Myxobolidae), a parasite of the teleost fish Prochilodus lineatus (Characiformes, Prochilodontidae) from the Paraná River, Brazil. Bull. Eur. Ass. Fish Pathol., 24(6): 308-311

Eiras J C,, Takemoto $\mathbf{R} \mathbf{M}$ and Pavanelli G.C. (2008). Henneguya caudiculan. sp. (Myxozoa, Myxobolidae) a parasite of Leporinus lacustris (Osteichthyes, Anostomidae) from high Parana river, Brazil, with revision of Henneguya spp infecting South American fish. Acta Protozool. vol. 47: 149-154.

E1- Matbouli M., T. Ficher- Scherl and R. W. Hoffman (1992): Present knowledge on the life cycle, taxonomy, pathology and therapy of some Myxosporea species important for freshwater fish. Annu. Rev. Fish Dis. Vol.3: 367-402.

Kalavati C, and C.C. Narasimahamurti (1985): Histopathological changes in the gills of Channa 
punctatus BL. infected with Henneguya waltairensis. Arch. Protistenkunde.vol. 129:199-202.

Kalavati, C. and N.C. Nandi (2007): Handbook of myxosporidean parasites of Indian fishes. Kolkata: Zoological Survey of India, 293 pp.

Kudo R.R. (1966): Handbook of Protozoology, Thomas, Springerfield publication, $5^{\text {th }}$ edition: $643 \mathrm{pp}$.

Lom, J. and I. Dykova (1992): Protozoan parasites of fishes. Developments in Aquaculture and Fisheries Science, vol. 26, Elsevier, 315 pp. Myxosporidea). Journal of wildlife diseases Vol. 11: 2-7.

Mccraren J.P., Landolt M.L., Hoffman G.L. and F.P. Meyer (1975): Variation in response of channel catfish to Henneguya sp. infections (Protozoa:
Molnar K. (1988): Taxonomic problems, seasonality and histopathology of Henneguya creplini (Myxosporea) infection of the pikeperch Stozostedion lucioperca in Lake Balaton. Folia Parasitol vol,45:261269.

Martins M.L. and V.N. Souza (1997): Henneguya piaractus $n s p$. (Myxozoa:Myxobolidae), a gill parasite of Piaractus mesopotamicus Holmbrrg, 1887 (osteichthyes: Characidae), in Brazil. Revista Brasileira de Biologia, vol.57,:239-245.

Okaeme, A.N., Obiekezie, A.I., Lehman, J., Antai, E.E. and Madu, C.T. (1988): Parasites and diseases of cultured fish of lake Kainji area Nigeria. Journal of Fish Biology 32: 479-481. 